\title{
WHAT HAPPENS WHEN ALL WE ARE LEFT WITH ARE THE INBRED AND SPOONFED?
}

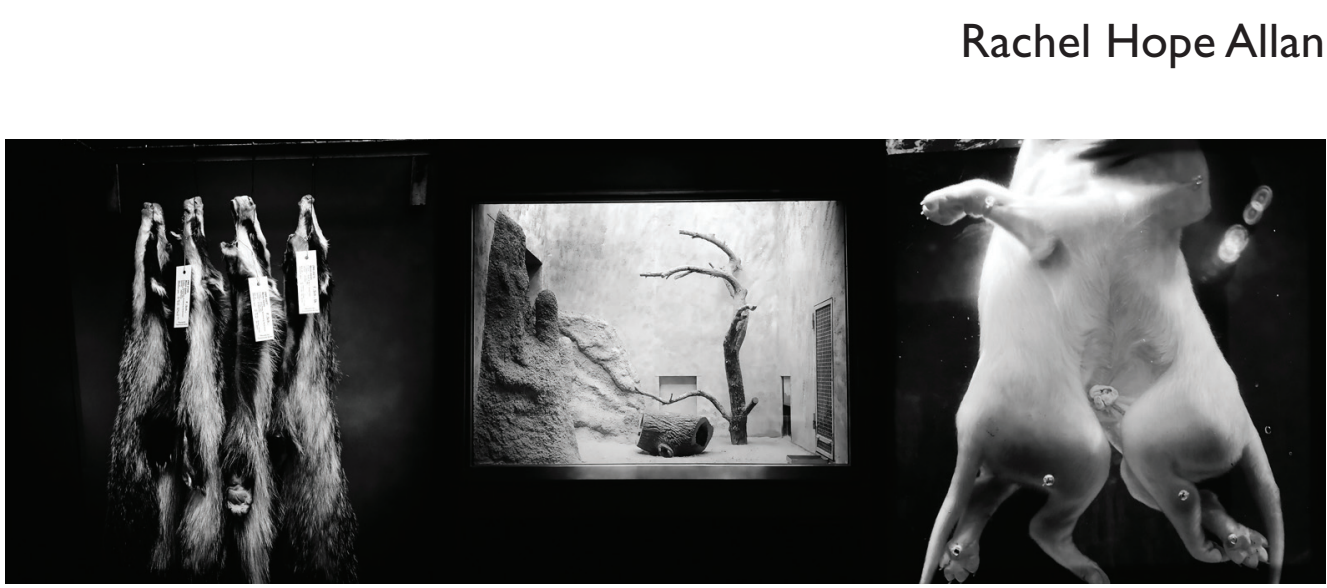

Figure I. Rachel Allan, Inbred \& Spoonfed, 20 I 8, archival print on Moab Slickrock Metallic paper 300gsm, I000 × 3000 mm.

The following text and images explore the motivation behind the exhibition "inbred \& spoonfed" that was held at Robert Piggott Art Gallery in 2018. The works in this show developed from the research and photographs that figured in the exhibition and subsequent publication, "coke \& popcorn" in 2015-16.

Animals have appeared in art for millennia as decorative motifs, objects of wonder and symbols of human triumphs and foibles. From the invention of photography through to the internet age, animals have been a frequent subject of the camera's lens, from portraits of beloved pets and exotic creatures to the documentation of human cruelty against them. Photographers are drawn to animal subjects, spanning the range from Count de Montizon's I 852 albumen print Hippopotamus at the Zoological Gardens, Regent's Park to Craigie Horsfield's colossal zoo photo-tapestries made from video stills (2007). More recently, Gucci's Wooster Street store in New York hosted an exhibition by photographer Paige Powell and Dashwood Books celebrating her life and work with a limited-edition book that included a volume dedicated solely to animals.' Furthermore, in Gucci's fall/winter 2018 fashion show, models were seen cradling lifelike models of Sphynx cats as they sashayed down the runway.

It is undeniable that we as a species have a fascinating relationship with animals. We share our homes with them and we cage them, we view them as entertainment and we consume them. In his book The Psychopath Test, Jon Ronson states that one of the stranger characteristics of psychopaths is their choice of pets. They are almost never cat people. "Because cats are willful."."

I believe that our childhood relationship with animals plays a major role in how we view them as adults. I spent the first eight years of my life in Feilding (in the Manawatu District of the North Island) and vividly recall school visits to the local meatworks and the sides of beef stamped 'NOT FOR EXPORT' in bright red ink. I remember the first time I saw a Skeptics ${ }^{3}$ music video set in a meatworks on the late-nightTV music show Radio with Pictures, and the subsequent uproar when mainstream media got hold of it. According to Stuart Page, who directed, shot and edited the video, the "song was written purely about some guys who 'pack meat' and the video was made in that light - not wanting to cast any aspersions on the workers in the meat trade - but to document the 'process' of a sheep's life in contemporary NZ:"4 
These formative experiences heavily influenced my relationship with animals and how I regarded them. Like many kids from Feilding, I had pet lambs growing up. They would appear in the backyard with a ribbon tied around their necks and for months they would be my closest companion, sleeping in my Wendy house, walking with me to school, until the day would arrive when they were no longer a pet lamb, but a sheep. I was always told that you never name your food. To this day I can recite off by heart all of my lambies' names, and I swear that none of them ended up in my belly.

Most of my childhood friends were lucky enough to have some kind of a pet growing up, and some of them even a horse. One of my most traumatic animal-related experiences (I have had a few) has to do with a horse, or more specifically a pony. I don't know quite where to start this story - I could ease you into it with descriptions of the driveway, the colour of the house, the breed of the yapping dog at my ankles, but I won't. All of that information isn't as important as the white pony. The white pony with a button where his eye should be. The shiny red button, tacked on as a placeholder - that shiny cherry-red button blanket stitched to his eyelid. That button has haunted me. As has the specific moment when I realised that I couldn't take him home, that I couldn't give him an eye patch or, at the very least, provide him with some superior suturing.

Based on Susan Sontag's proposition that "[p]hotographs cannot create a moral position, but they can reinforce one - and can help build a nascent one," the snapshot and studio image. "inbred \& spoonfed" tells a story. It is an ode to all my creatures - the ones tattooed on my body, those that share my home, haunt my dreams, inhabit this earth and have buttons for eyes. Challenging preconceived and outdated notions of photography and the ghettoisation of digital, I place photographic works that are framed and unframed, printed on photographic and non-photographic materials, captured on iPhone and film camera beside each other, allowing the image to do all the work.

Like so many things, photography has become nonhuman, and although it has moved away from the human-centric view of its creation, it consistently reminds me of my inevitable death and the death of those I cherish and my inability to escape the datum that death and photography are inextricably linked. "inbred and spoonfed" is caught in that in-between place of pleasure and depression. The photographs have blacks so thick they get stuck in your back teeth; they explore notions of loss and the fetishisation of processes, animals and objects. They are the evidence of a practice that is drenched in nostalgia.

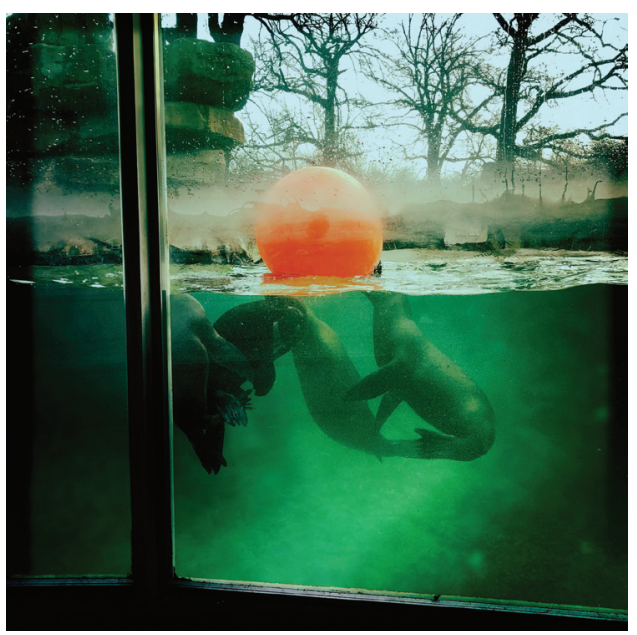

Figure 2. Rachel Allan, Sex, Death \& Jerry-lee Lewis, 2018, archival print on Moab Slickrock Metallic paper 300gsm, $1000 \times 1000 \mathrm{~mm}$.

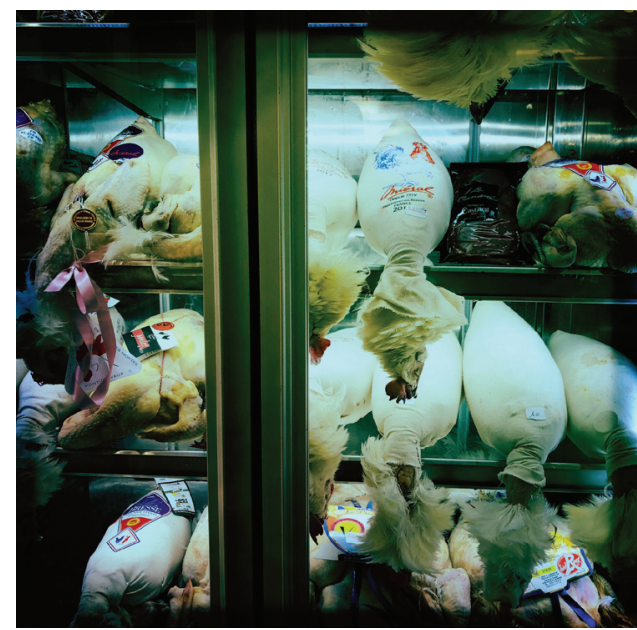

Figure 3. Rachel Allan, Ribbons \& Combs, 2018, archival print on Moab Slickrock Metallic paper 300gsm, $1000 \times 1000 \mathrm{~mm}$. 
Contained within a thick black frame is my imaginarium, where empty enclosures morph with institutional objects and creatures both alive and dead pose for the camera. Printed on metallic silver paper, the images reveal the eerie spectre of the viewer that echoes the detached, manicured and sterile way in which we now view these creatures. The tableau featuring the man-sized skinned badgers and headless quarantined specimens asks what will be left if our species continues to consume and crop at our present alarming rate. The scale of the works, some over one metre high by three metres long, dwarfs the viewer, placing them literally face to face with the dead, dying and detained. The images force you to recall childhood trips to the zoo and the eyes of that lonely, hot polar bear living out its days in an artificial environment. Your hands become sticky and you can almost smell the urine-soaked hay and hear the quiet cooing of the ever-present pigeon. You swear you can taste formaldehyde in the air as you are forced into pressing your nose up to the glass.

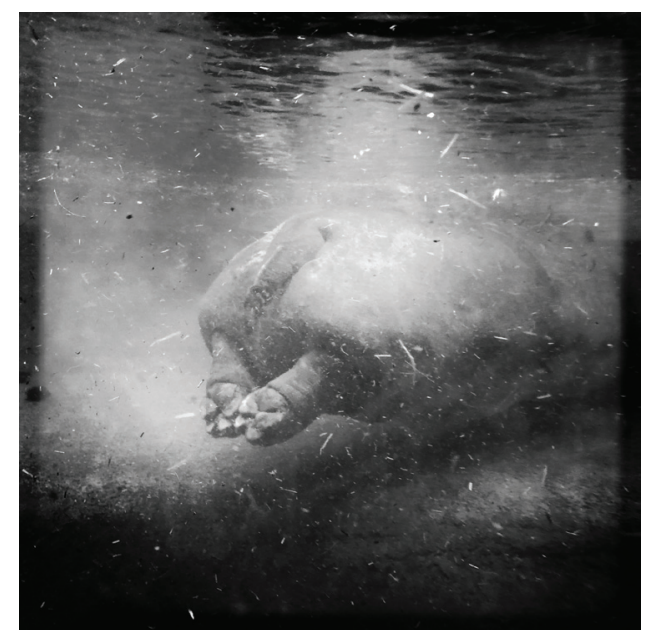

Figure 4. Rachel Allan, Bahnhof Zoo, 2018, archival print on Moab Slickrock Metallic paper 300gsm, 500 × 500 mm.

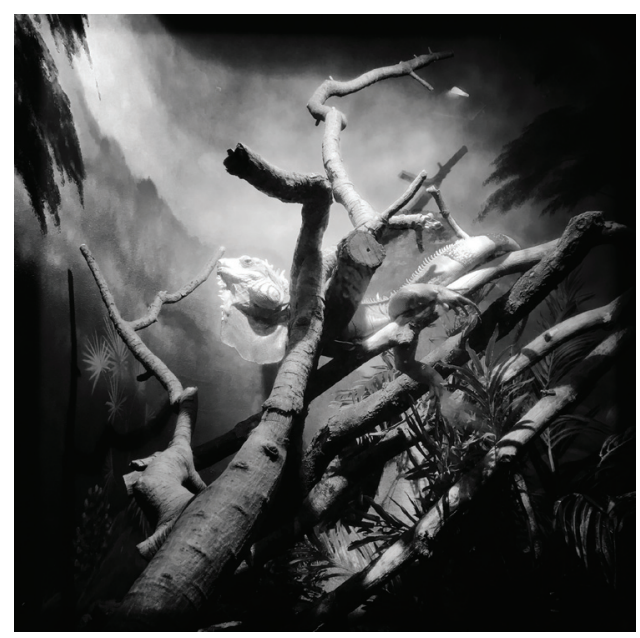

Figure 6. Rachel Allan, Not Quite Gowanus Canal, 2017, archival print on Moab Slickrock Metallic paper 300gsm, $500 \times 500 \mathrm{~mm}$.

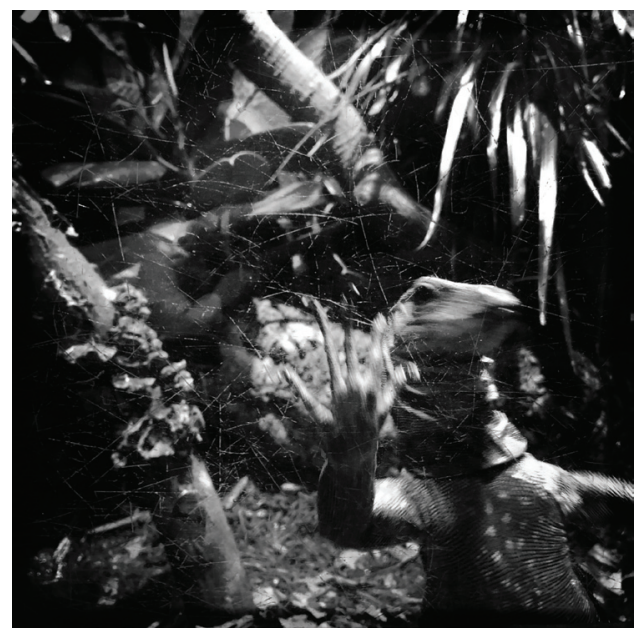

Figure 5. Rachel Allan, Behind the Glass, 20 I6, archival print on Moab Slickrock Metallic paper 300gsm, $500 \times 500$ mm.

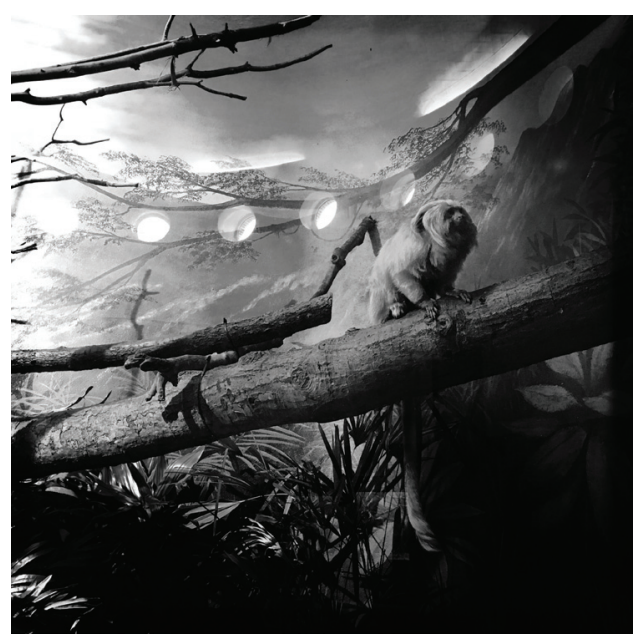

Figure 7. Rachel Allan, Tears Before Bed, 2017 archival print on Moab Slickrock Metallic paper 300gsm, $500 \times 500 \mathrm{~mm}$. 
As a child, my aunty used to tell me stories about how she used to ride the horses that were destined for the lion's dinner. She would jump the fences behind the zoo and break into the enclosures where the zoo kept the animals that were fated to be the apex predator's next meal. She would reminisce about using her cardigan as reins and would relay the anguish she felt when each week she would return, a horse would be missing, and how each time she wished she could save them. I have often thought of this story and sometimes lie in bed at night making lists of the creatures I would save if I couldn't save them all. According to the Centre for Biological Diversity, "We're currently experiencing the worst spate of species die-offs since the loss of the dinosaurs 65 million years ago." 6 Each day our news media are filled with alarming statistics or horrific stories demonstrating our inevitable demise. Sudan, the last male northern white rhino, died in March 2018. If humans do indeed see animals as surrogates of themselves, as proposed by Arnold Arluke and Clinton R. Sanders in their book Regarding Animals, ${ }^{8}$ what does that say about us?

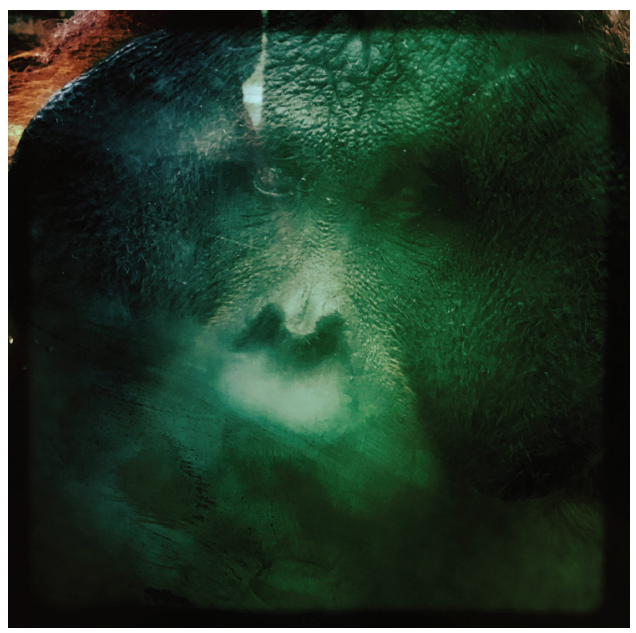

Figure 8. Rachel Allan, 2 Trains and a Monorail, 2017 , archival print on Moab Slickrock Metallic paper 300gsm, $1000 \times 1000 \mathrm{~mm}$.

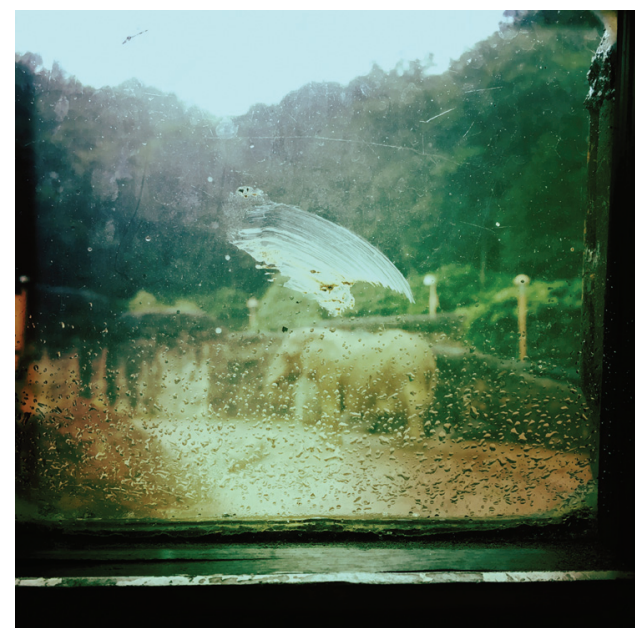

Figure 9. Rachel Allan, Smudge, 2017, archival print on Moab Slickrock Metallic paper 300gsm, $1000 \times 1000 \mathrm{~mm}$.

Over the past three years I have visited enclosed animals in Amsterdam, Japan, Germany, France, the United Kingdom and the US.I have hidden from mountain lions at the old abandoned Los Angeles Zoo and surreptitiously photographed specimens at the world's leading parasite museum. I have stood where Sugimoto famously performed his long exposures at the Natural History Museum in New York, and spent a snowy Christmas Day in the world's oldest zoo. I witnessed the aftermath of the great fire of 2017 at the penguin enclosure at London Zoo, and sat palm to palm with the oldest orangutan in captivity.

In order to complete this series of photographs, I had to become somewhat detached. I was both repulsed and compelled by what I saw and quite often had to shoot while tears ran down my cheeks and fogged up my glasses. You see, I was kind of stuck. I found myself paying entrance fees and financially supporting institutions that I detested, hoping that my admission fee was being reinvested in the captives' welfare - fingers crossed and all that. Marianne Macdonald of SAFE (Save Animals from Exploitation) believes people should boycott zoos: "I think people need to seriously question whether that's what they want to do with their money.... Zoos are definitely something that needs to be consigned to the history books. The treatment of animals in zoos is not outright abuse, but in a lot of cases, particularly for the larger animals, they cause extreme deprivation because they are in such a restricted environment."' Somehow, on the date of my birth, I found myself in an aquarium ${ }^{10}$ on top of a 60 -story building in Ikebukuro, Tokyo, face to face with a seal. The site, Sunshine City, is billed as a city within a city and is ironically built on land once occupied by a prison. 
Ultimately children and adults always find themselves dissatisfied by viewing animals sitting listlessly in enclosures. I have heard the question "Is he dead?" being uttered in many languages, because underneath all the flash conservation talk zoos are all the same. Zoos are depressing places. They are museums of living corpses; some species only exist in the gilded cages we have constructed, catalogued and barcoded - classified confirmation of our feast of destruction. And then there are the museums, packed full of carcasses - the marble tombs that hold the evidence of our perceived dominance. Then alsothe supermarkets with over-stuffed fridges. The pet stores with dying stock that deliver corroboration of our inability to recognise that the reservoir is running dry and the biodiversity of this planet is shrinking at an alarming rate.

According to Jesse Golden of New Zealand's Hamilton Zoo: "The animals we have in our zoo and the other zoos we work with are creating an insurance population, so that one

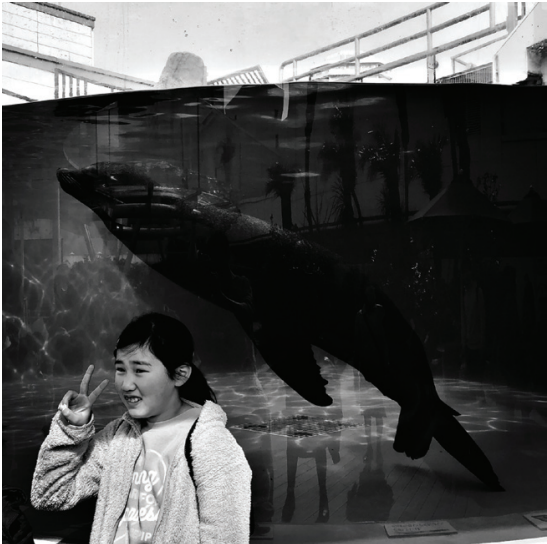

Figure 10. Rachel Allan, サンシャインシティ archival print on Moab Slickrock Metallic paper $300 \mathrm{gsm}, 1000 \times 1000 \mathrm{~mm}$. day when things do improve we could potentially help their range countries with their conservation work and maybe bring that wildlife back and assist them with that."' But he also reveals what we all fear is true: "There's not much of a future for them right now, things are looking quite bleak for them out in the wild."'12

Humanity has wiped out 60 percent of wild animal populations since 1970 and we are facing a mass extinction. According to Taranaki Daily News journalist Helen Harvey, "while zoo advocates believe modern, or progressive, zoos are important for conservation, research and education, others think zoos should be consigned to history. And actually, Auckland Zoo director Kevin Buley partly agrees with that sentiment. He reckons 95 per cent of the world's zoos should be shut down tomorrow."' "I "Inbred \& spoonfed" is a lens on what happens when we do no more than comment on posts by trophy hunters and press sad face when Grumpy Cat 'passes away.'When we watch documentaries about pit bulls being rehabilitated by prison inmates, but won't donate to Dunedin Dog Rescue. The bees continue to die and I prepare baths for my inbred/purebred Sphynx cats and take extra care of Miss Myrtle with her one eye.

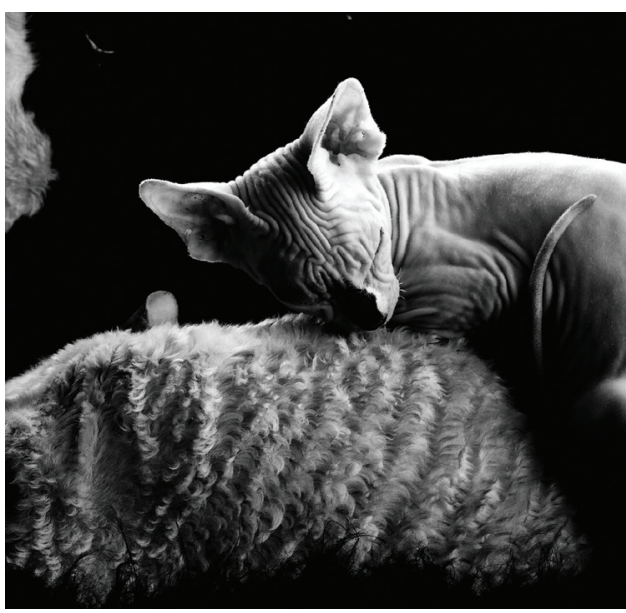

Figure II. Rachel Allan, No Need for Buttons, 2019, archival print on Moab Slickrock Metallic paper 300gsm, $500 \times 500 \mathrm{~mm}$.

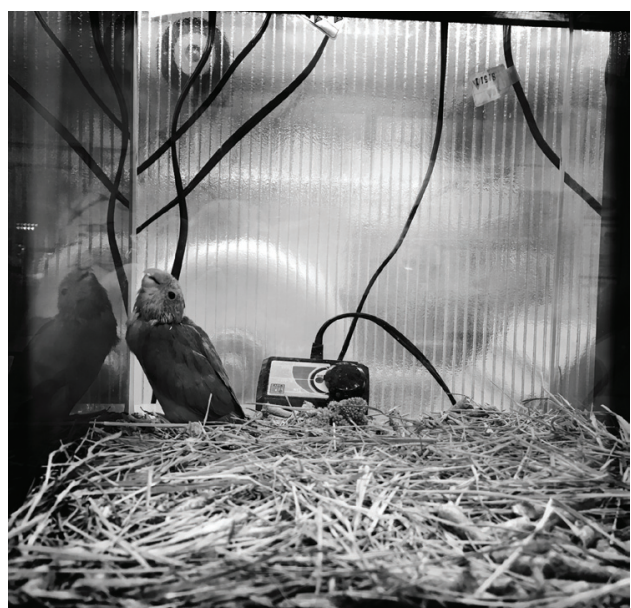

Figure 12. Rachel Allan, Tokyo Hands, 2018, archival print on Moab Slickrock Metallic paper 300gsm, $500 \times 500 \mathrm{~mm}$ 
Rachel Hope Allan holds a Master of Fine Arts (with distinction) from Dunedin School of Art, New Zealand where she currently lectures in photography and electronic arts. She has exhibited both locally and internationally most recently at The Jarvis Dooney Galerie, Berlin, Germany (2019 \&20।8), Wallplay, New York, USA (2017), The Yu Gallery, Shanghai (2017), The Tokyo International Art Fair, Tokyo (2018 \& 2017), The Dunedin Public Art Gallery (2016) and Getty Images Gallery, London (2016). Her published artist-books are held in The Angela Morton Collection, Auckland City Library, The National Library of New Zealand, The University of Otago, Hocken Collections, The University of Canterbury and The Reminders Photography Stronghold, Tokyo, Japan.

Her research practice is wide-ranging, extends from traditional, darkroom-based processes through to digital and alternative liquid photography. Dealing with restraint, curiosity and mimicry, she is interested in using her work to challenge perceptions of reality, and to explore the fetishisation of processes and objects.

I Steff Yotka, "Gucci Celebrates Photographer Paige Powell with an In-store Installation," Vogue, 19 April 2019, https://www. vogue.com/article/gucci-photographer-paige-powell; Paige Powell, Paige Powell, 4 vols (New York: Dashwood Books, 2019).

2 Jon Ronson, The Psychopath Test: A Journey Through the Madness Industry (London: Picador, 20I I).

3 The Skeptics were a New Zealand post-punk band active between 1979 and 1990. The music video I refer to here is AFFCO, which was partially filmed in a meatworks. The lead singer spends most of the video wrapped in clingfilm covered in blood. https://www.youtube.com/watch?v=cyjVGIQdt2k.

4 Stuart Page, "The Truth about the Skeptics' A.F.F.C.OVideo," http://vital.org.nz/stu.html.

5 Susan Sontag, On Photography (London: Penguin, 1977), 17.

6 Doyle Rice,"These SpeciesWent Extinct in 20 I 8.More Maybe Doomed to Follow in 20 I 9,"USAToday, 3 I December 20 I 8, https:// www.usatoday.com/story/news/nation/2018/I2/31/extinct-species-these-animals-were-lost-forever-2018/2450 I 21002/.

7 Sarah Gibbens, "Last Male Northern White Rhino Sudan Remembered in Ceremony," National Geographic, 3I March 20 I8, https://news.nationalgeographic.com/2018/03/sudan-last-male-northern-white-rhino-extinct-spd/.

8 Arnold Arluke and Clinton R Sanders, Regarding Animals (Philadelphia, PA:Temple University Press, 1996).

9 Helen Harvey, "To Go or not to Go to the Zoo Tomorrow," Taranaki Daily News, 30 November 20 I 8, https://www.stuff.co.nz/ taranaki-daily-news/news/ | 08862906/to-go-or-not-to-go-to-the-zoo-tomorrow?fbclid=|wAROr_BjRIFB7KgEA5mOZsSxZz | viHDn5IWTbeL5beeRIDg94cnpPFe0NCss.

10 Sunshine Aquarium, https://sunshinecity.jp/en/aquarium/.

I I RNZ, "Work with Endangered Animals is Insurance Policy for Future, Zoo Says," MSN News, 20 April 2019, https://www.msn. com/en-nz/news/national/work-with-endangered-animals-is-insurance-policy-for-future-zoo-says/ar-BBW8psT.

12 Ibid.

I3 Harvey, "To Go or not to Go to the Zoo Tomorrow." 